\title{
The Moral Arc of the Library: What Are Our Duties and Limitations After 45 ?
}

Jennifer Stout

vCU Libraries, jastout@vcu.edu

Kelsey Cheshire

vCU Libraries, kcheshire@vcu.edu

Follow this and additional works at: https://scholarscompass.vcu.edu/libraries_pubs

Part of the Library and Information Science Commons

Copyright (C 2020, Emerald Publishing Limited. This work is licensed under a Creative Commons Attribution Non-commercial International Licence 4.0 (CC BY-NC 4.0)(https://creativecommons.org/ licenses/by-nc/4.0/).

\section{Recommended Citation}

Cheshire, K. and Stout, J. (2020), "The moral arc of the library: what are our duties and limitations after 45?", Reference Services Review, Vol. 48 No. 2, pp. 219-225. https://doi.org/10.1108/RSR-10-2019-0074

This Article is brought to you for free and open access by the VCU Libraries at VCU Scholars Compass. It has been accepted for inclusion in VCU Libraries Faculty and Staff Publications by an authorized administrator of VCU Scholars Compass. For more information, please contact libcompass@vcu.edu. 
The Moral Arc of the Library: What Are Our Duties and Limitations After 45?

\begin{tabular}{|r|l|}
\hline Journal: & Reference Services Review \\
\hline Manuscript ID & RSR-10-2019-0074.R2 \\
\hline Manuscript Type: & Original Article \\
\hline Keywords: & $\begin{array}{l}\text { code of ethics, neutrality, vocational awe, Social justice, 45th } \\
\text { administration, Librarianship }\end{array}$ \\
\hline \multicolumn{2}{|l}{} \\
\hline
\end{tabular}

\section{SCHOLARONE \\ Manuscripts}




\title{
The Moral Arc of the Library: What Are Our Duties and Limitations After 45?
}

\author{
Kelsey Cheshire, Virginia Commonwealth University \\ Jennifer Stout, Virginia Commonwealth University
}

\begin{abstract}
Purpose -- This think piece explores the question of whether or not librarians can ethically remain politically neutral in the wake of the 45th administration. The authors take a critical look at ALA's Code of Ethics, as well as the concept of vocational awe, and recommend challenging the "sacredness" of neutrality as a core tenet of the profession. Additionally, the authors describe the history of white privilege within libraries and argue that it is time to actively fight white supremacy and disavow the profession's history of replicating racist social structures.

Design/methodology/approach -- This article is a researched think piece designed to encourage critical thought about long held idealistic beliefs in our profession.

Findings -- Our research suggests that despite the profession's history of outwardly valuing "neutrality', libraries are not and have never been neutral. Libraries have chosen, time and again, to value white privilege and a white frame of reference to the detriment of librarians and patrons of color. Because many librarians also see the profession as upholding "sacred" ideals like neutrality, we fall into the trap of being unable to criticize our own profession and practices and, therefore, are unable to make much needed changes.
\end{abstract}

Research limitations/implications -- This piece is based on the opinions of the authors and on the opinions of authors they have cited. It contains no original quantitative or qualitative research.

Originality/value -- This piece challenges long-held assumptions that the profession has taken for granted over the past century. We argue that it is good and necessary to question the Code of Ethics, vocational awe, and neutrality with the goal of improving the profession in light of the current cultural and political climate.

Keywords -- Neutrality, vocational awe, code of ethics, social justice, 45th administration, librarianship

Paper type -- Think piece

\section{Introduction}

“This is not normal."(Blow, 2016)

This is the refrain we've heard over and over ever since the 2016 election. The United States has seen presidents engage in corrupt activities, war-mongering, invasions of privacy, and many other disturbing activities over the past two centuries, but this president and his administration's activities are alarming and represent a momentous paradigm shift in our history. As libraries and institutions committed to freedom of information, we must respond. 
On one hand, the profession has always upheld principles such as access to information, privacy and confidentiality, and a distinction between personal conviction and professional duties, as outlined in the American Library Association (ALA) Code of Ethics (2008). While many of those principles maintain a clear ethical standpoint for librarians, others are more challenging. The actions of the $45^{\text {th }}$ administration are not coming from a new playbook. What has changed, and what continues to need to change, is the movement for libraries to disavow white supremacy and hate speech, despite their long history of upholding institutional oppression (de Jesus, 2014). As Honma (2005) so eloquently stated, "All too often the library is viewed as an egalitarian institution providing universal access to information for the general public. However, such idealized visions of a mythic benevolence tend to conveniently gloss over the library's susceptibility in reproducing and perpetuating racist social structures found throughout the rest of society." Over a decade later, the $45^{\text {th }}$ administration embodies that paradox as librarians of dominant groups come to grips with their unearned privileges and the difficult place of libraries in history, and their eager desire to now proactively fight oppression.

In the spirit of author acknowledgements that recognize privilege and status (Brook et al., 2016), this viewpoint is written by two white, cisgender librarians who have done reference and instruction work in various university libraries. The authors acknowledge our many unearned privileges, which shape our ability to write this viewpoint, and remain indebted to our colleagues of color who have shaped our understanding of these issues.

\section{Introduction to Code of Ethics}

The ALA Code of Ethics is implicitly seen as sacred to many in the profession. It is akin to our Hippocratic Oath. We are expected to provide access to information, regardless of what that information is or who is asking for it. We are expected to resist all efforts of censorship, no matter the content. We protect privacy in an age where data are the most valuable commodity available. After our LIS education, however, we quickly realize that holding up the Code of Ethics only truly works in an ideal world. Most practicing librarians can quickly offer up a personal example of their ethics being challenged at the workplace. As ALA explains, "Ethical dilemmas occur when values are in conflict...The principles of this Code are expressed in broad statements...statements provide a framework; they cannot and do not dictate conduct to cover particular situations."

Consider the Connecticut Four (Jones, 2009): four librarians who challenged the PATRIOT Act in order to protect the privacy of their library users. In this case, the request for information was in direct conflict with patron privacy, and George Christian, Peter Chase, Barbara Bailey, and Jan Nocek chose to uphold one ideal against another. In this example, they were acting to uphold the right to privacy as described in the Code of Ethics over legislation disguised as necessary for national security. To many of us, this is exactly the guidance that the Code of Ethics should provide our profession. We've been indoctrinated to fight for privacy, and in the face of the USA government, the Connecticut Four advocated for our users' right to privacy. Librarians were expected to applaud this effort, including those most concerned about national security post $9 / 11$. 
The Code of Ethics is an ideal and clear-cut document in an imperfect and complex society. It still provides an excellent framework for us, as demonstrated in the case of the Connecticut Four, but it can be improved with additional acknowledgements of the reality of the profession. For example, Principle VII states, "We distinguish between our personal convictions and professional duties and do not allow our personal beliefs to interfere with fair representation of the aims of our institutions or the provision of access to their information resources" (American Library Association, 2008). Many can agree this has always been the most difficult principle to follow, as we are human beings with personal beliefs. This statement assumes that librarians are always capable of maintaining neutrality. Emily Drabinski (2018) points out, "The debate about neutrality in libraries asks us to imagine a world where those real things are and infinitely fungible... all of us who work in libraries know, each choice we make for something is a choice against some other thing." We preach unrestricted access to information, yet we make judgement calls to restrict access every day. In collecting, choosing one book means not choosing another. In limiting patrons under a certain age to checking out books from children and young adult collections, we are restricting access or at least adding obstacles to completely free access. In using web filters on public computers, we are restricting access. The examples of our work failing neutrality are endless. Making judgement calls that don't perfectly uphold our ideals is nothing new or unusual to us. Honma (2005) says of our shared conundrum, "Such is the dilemma of LIS. Information devoid of a social context fails to live up to its potential as a transformative agent in a world increasingly shaped by racial inequality and the global spread of neoimperialist capitalism." Therefore, libraries fail to live up to their potential. Our profession wants desperately to live up to our potential, so why is the concept of making judgement calls in the Trump era something many of us struggle with mightily?

The recent controversy over the language in the "meeting rooms" ALA document shows that we struggle in drawing firm lines even when it would likely be in the best interest for our patrons. The "Meeting Rooms: An Interpretation of the Library Bill of Rights" (American Library Association, 2019) document affirms that many libraries offer free meeting space to a wide variety of groups and do not discriminate based on religious or political affiliation. But the exact term "hate groups" was in the original document and after backlash, it was stricken from the document. As James LaRue (2018), Director of ALA's Office for Intellectual Freedom pointed out, new rights for hate speech were not established: "ALA does not endorse hate groups, and does not seek to normalize hate speech. But it recognizes that 'hate groups' is a remarkably elastic term, prone to be thrown about by both sides of a political spectrum. It has been attached to book discussion groups, Black Lives Matter, Muslim groups, and others". If we explicitly affirm the rights of "hate groups" on the grounds of access for all, we are actually becoming less accessible to other patrons. Hate speech leaves the realm of ideas and manifests into action, as we witnessed in Charlottesville and other recent hate crimes. White supremacy and neo-Nazism have never been just "viewpoints". They reflect lifestyles that involve inciting and even acting on violent impulses against others based on their race, religion, or ethnicity. Even worse, neo-Nazism and white supremacy has not been explicitly denounced by our current president. Rather, he says that "there are fine people on both sides." Given this reality, we should not allow hate groups a meeting space in our libraries. 
We also shouldn't allow contrarians to define hate groups as they see fit. By allowing others to dictate the terms of the argument, they are destined to win (Josey, 1973). The Southern Poverty Law Center (SPLC) defines "hate groups" as "organization[s] that - based on its official statements or principles, the statements of its leaders, or its activities - has beliefs or practices that attack or malign an entire class of people, typically for their immutable characteristics" (2017). According to this definition, neo-Nazis and the Ku Klux Klan would be considered hate groups, whereas the Black Lives Matter movement would not be considered a hate group and LaRue's argument does not hold up. LaRue's comment that hate groups "is a remarkably elastic term" only makes sense when we allow actual hate groups to define the terms for us. We must look to experts, such as the aforementioned SPLC, for guidance rather than allow others to make bad faith arguments.

\section{The Trap of Vocational Awe}

In her revelatory article, Fobazi Ettarh describes vocational awe as "the set of ideas, values, and assumptions librarians have about themselves and the profession that result in beliefs that libraries as institutions are inherently good and sacred, and therefore beyond critique" (2018). While this might sound like a positive framing of our work, Ettarh outlines the dangers of such a mindset about the library profession. Namely, that vocational awe makes it very difficult to question or critique our own practices and values. "Because the sacred duties of freedom, information, and service are so momentous, the library worker is easily paralyzed...Awe is easily weaponized against the worker, allowing anyone to deploy a vocational purity test in which the worker can be accused of not being devout or passionate enough to serve without complaint." We see this all the time when libraries make firm decisions to not collect a particular author. We also see it emerge during difficult discussions about diversity and inclusion in libraries. Ettarh points this out, writing "But because vocational awe refuses to acknowledge the library as a flawed institution, when people of color and other marginalized librarians speak out, their accounts are often discounted or erased."

What is the solution to vocational awe? Ettarh, in her conclusion, points to the importance of the person over the library. She writes, "Libraries are just buildings. It is the people who do the work. And we need to treat these people well" (2018). While she is specifically talking about library employees and how we should not view ourselves as martyrs, we extend this to the patron as well. We can't truly serve our patrons properly if we uphold ideals over our patron's humanity. The idea of vocational awe has everything to do with our current political and social climate. It serves to uphold values and ideals in the face of complex changes. To say we are neutral in a society where blatantly false information runs rampant (Barthel, Mitchell, \& Holcomb, 206), hate crimes are rising (Balsamo, 2018), and organized efforts towards censorship are occurring (Jacobson, 2017) is foolish. Now more than ever, it is difficult to view neutrality as wholly virtuous. It is worth looking at our collections, our policies, and even at our profession's Code of Ethics to interrogate if what we believe and what we practice are leaving our most vulnerable patrons at a disadvantage. We cannot be equally accommodating to vicious racist beliefs and to patrons of color. To pretend we can be "neutral" on this topic is naive at best, and racist in itself at worst. 


\section{Why It Is Time for Change}

If it seems that it all comes down to the question, "should libraries be neutral?", the authors of this piece would like to argue that this shouldn't even be a question: libraries in both theory and practice are not neutral. We can't be neutral and also hold up our Code of Ethics. The affirmation of freedom and access to information is not neutral. The act of providing information for free or at a low cost is not neutral. The choices we make in collecting certain materials and not collecting other is not neutral. All these arguments over the value of neutrality are null and void when the reality is that we are not, cannot, and will never be neutral.

"Libraries and professional organizations have put together documents and policies on information ethics and intellectual freedom in an attempt to broaden the professional perspective. While these are important policies and procedures, they still reinforce cultural hegemony as they are primarily written in the language of those in power. For example, statements on professional ethics are put together by professional organizations, the overwhelming majority of whose members are white. Intellectual freedom is influenced by the discursive formations of those who write and enforce these policies. It is those in power who decide what level of intellectual freedom the library will support" (Adkins and Hussey, 2006)

Questioning our Code of Ethics becomes more imperative as white librarians gain new insight into previously held assumptions about ideas of civility and professionalism. Espinal explains standards of civility and professionalism as such, “... in a white-dominated society, standards are applied and are described as neutral, universal, and true for all people. But in fact the criteria are not universal. They come from a white perspective" (2001). We now understand how these terms and concepts are often used to police people of color, marginalize minorities, and uphold the patriarchy and white supremacy. When someone is questioning professionalism as it is tied to neutrality, they are making assumptions that are often founded on ideals of white supremacy. Okun (2001) created a list of characteristics of white supremacy culture, some of which we can identify in our Code of Ethics. Not only beliefs of objectivity, but also a 'worship of the written word' are rooted in white supremacy. Combine the two concepts, and one can see why this struggle between our Code of Ethics and advocacy exists.

What is and is not acceptable professional behavior should not be viewed only through the eyes of white men. As Sara Ahmed (2017) has explained, when we refer to white men we are referring to an institution. This institution has prioritized racist expectations over our colleagues of color. What once seemed like a professional standard of neutrality should now be filtered through an intersectional feminist perspective. Librarians should educate themselves on the historic nature of the concepts of civility and professionalism, reflect on how these false narratives have shaped our Code of Ethics, and then regroup to reassess what is our pathway forward.

In the face of increased understanding of the role whiteness and white privilege has played in the history of the library profession, and in the face of the violations of our country's most cherished ideals at the hands of an authoritarian administration, it is time for libraries and librarians to do away with arguments about "neutrality" and instead reorient ourselves toward 
social justice in a more intentional way. Over two decades ago, Rubin argued that we reinterpret libraries and librarians as "agents of authority and social control" (as cited in Honma, 2005). ALA has taken small steps recently, including acknowledging the rise of hate crimes in libraries by publishing resources in "Hateful Conduct in Libraries: Supporting Library Workers and Patrons" (2018). More is needed in order to offer support and guidance for librarians in the face of the $45^{\text {th }}$ administration and its supporters. For example, Jaeger and Taylor (2019) point out that librarians can become more involved in information policy based on our expertise. "Our institutions are trusted by the public and have a great deal to contribute to public discourse, if we just learn to trust ourselves." While they maintain "we do not need to side with specific political candidates or parties," one could easily argue that that is a pipe dream with the current political divide.

We continuously need to critically analyze how we approach issues such as censorship and information literacy, because these issues are intertwined with our conflict. We can't applaud ourselves for fighting censorship without acknowledging the irony that being anticensorship often inadvertently silences minority voices while amplifying those of dominant groups. Iverson calls attention to our history with anti-censorship, stating, "While librarians have been avidly anti-censorship, they have not been avidly anti-racist and they do not acknowledge the inherent racism with the discourse of anti-censorship" (1993). As a profession, we are quick to advocate for our institution, and less quick to advocate for our patrons. This must change. As Brook, et al. have outlined, "As a conflict-averse profession, librarianship must begin to recognize conflict as potentially productive, and not only as bare antagonism...discord is painful but it can also be transformative" (2016).

\section{Conclusion}

In "Speech in the Workplace Q\&A," ALA (2017) says in issues about policies deemed detrimental to the public interest or to the profession, "...you should and probably will feel an ethical obligation as a professional to speak out and make your library values known. You will have to use your professional judgment as to when and how to do so, and you must be prepared to accept any potential consequences." There has never been a more crucial time for librarians to speak out and make our values known--values beyond those described in the Code of Ethics. The potential consequences aren't hard to imagine, particularly the consequences that come with inaction. The Code of Ethics still provides an admirable framework for us, but it can be improved with additional acknowledgements to the reality of the profession. It is interesting that in "Core Values of Librarianship" (2006), ALA acknowledges the potential for more advocacy by saying, "The broad social responsibilities of the American Library Association are defined in terms of the contribution that librarianship can make in ameliorating or solving the critical problems of society." Such a lofty statement implies work beyond what we are currently doing. Last updated in 2008, we ask that you consider how the $45^{\text {th }}$ administration could lead to another revision of the Code of Ethics. There would undoubtedly be dissenters to any changes, fearing the implications of anti-neutrality or the other 'sacred' ideals of our profession. Rather than relying on ALA for leadership during this tumultuous period, will librarians be forced to look for ethical guidance through another professional organization or personal source? At the end of the 


\begin{abstract}
day, we should ask ourselves how much the Code of Ethics and ALA actually steer our daily actions and decisions. If you think the Code of Ethics is what is stopping you from taking sides in an increasingly dangerous world, stop to think: is it really the written word, or is it the outdated and biased thinking that has historically informed our profession?
\end{abstract}




\section{References}

Adkins, D., Hussey, L. (2006) 'The Library in the Lives of Latino College Students', The Library Quarterly, 76, p456-480. Available at: https://doi.org/10.1086/513862

Ahmed, S. (2017) Living a feminist life. Durham: Duke University Press.

American Library Association. (2019) Meeting Rooms: An Interpretation of the Library Bill of Rights [Online]. Advocacy, Legislation \& Issues. Available at: http://www.ala.org/advocacy/intfreedom/librarybill/interpretations/meetingrooms

American Library Association. (2018) Hateful Conduct in Libraries: Supporting Library Workers and Patrons [Online]. Advocacy, Legislation \& Issues. Available at: http://www.ala.org/advocacy/hatefulconduct

American Library Association. (2017) Speech in the Workplace $Q \& A$ [Online]. Tools, Publications \& Resources. Available at: http://www.ala.org/tools/ethics/workplacespeechqa

American Library Association. (2008) Code of Ethics of the American Library Association [Online]. Available at http://www.ala.org/tools/ethics

American Library Association. (2006) Core Values of Librarianship [Online]. Advocacy, Legislation \& Issues. Available at: http://www.ala.org/advocacy/intfreedom/corevalues

Balsamo, M. (2018) FBI report shows 17 percent spike in hate crimes since 2017 [Online]. AP News. Available at: https://apnews.com/e5e7bb22f8474408becd2fcdc67f284e

Barthel, M., Mitchell, A., Holcomb, J. (2016) Many Americans Believe Fake News is Sowing Confusion [Online]. Pew Research Center. Available at https://www.journalism.org/2016/12/15/many-americans-believe-fake-news-is-sowingconfusion/

Blow, C. M. (2016) This is Not Normal! [Online]. The New York Times. Available at: https://www.nytimes.com/2016/12/19/opinion/donald-trump-this-is-not-normal.html

Brook, F., Ellenwood, D., Lazzaro, A.E. (2016) 'In Pursuit of Antiracist Social Justice: Denaturalizing Whiteness in the Academic Library', Library Trends, 64(2) [Online]. Available at: https://muse.jhu.edu/article/610078

de Jesus, N. (2014) 'Locating the Library in Institutional Oppression', In the Library with the Lead Pipe, [Online]. Available at: http://www.inthelibrarywiththeleadpipe.org/2014/locating-the-library-in-institutionaloppression/

Drabinski, E. (2018) Are libraries neutral? [Blog] Emily Drabinski. Available at: http://www.emilydrabinski.com/are-libraries-neutral/

Espinal, I.R. (2001) 'A New Vocabulary for Inclusive Librarianship: Applying Whiteness Theory to Our Profession' in REFORMA. The Power of Language=El poder de la palabra. Englewood, Colorado: Libraries Unlimited pp. 131-149.

Ettarh, F., 2018. 'Vocational Awe and Librarianship: The Lies We Tell Ourselves', In The Library With The Lead Pipe, [Online]. Available at: http://www.inthelibrarywiththeleadpipe.org/2018/vocational-awe/

Honma, T. (2005) 'Trippin' Over the Color Line: The Invisibility of Race in Library and Information Studies', InterActions: UCLA Journal of Education and Information Studies, 1(2) [Online]. Available at: https://escholarship.org/uc/item/4nj0w1mp 
Iverson, S. (1993) 'Librarianship and Resistance' in Lewis, A. (ed.) Questioning Library Neutrality. Duluth: Library Juice Press, pp. 25-32.

Jacobson, R. (2017) Internet Censorship is Advancing Under Trump [Online]. Wired. Available at: https:/www.wired.com/2017/04/internet-censorship-is-advancing-under-trump/

Jaeger, P.T., Taylor, N.G. (2019) Battling Information Illiteracy [Online]. American Libraries Magazine. Available at: https://americanlibrariesmagazine.org/2019/07/17/battlinginformation-illiteracy/

Jones, B.M. (2009) 'Librarians Shushed No More: The USA Patriot Act, the "Connecticut Four," and Professional Ethics', Newsletter on Intellectual Freedom, [Online]. Available at https://www.ifla.org/past-wlic/2009/117-jones-en.pdf

Josey, E.J. (1973)' Social Responsibility and the Library Bill of Rights: The Berninghausen Debate', Library Journal, 98, p32-33.

LaRue, J. (2018) Library Meeting Rooms for All [Blog]. Intellectual Freedom Blog. Available at: https://www.oif.ala.org/oif/?p=14997

Okun, T. (2001) White Supremacy Culture. Available at: http://www.dismantlingracism.org/whitesupremacy-culture.html

Southern Poverty Law Center (2017) Frequently asked questions about hate groups [Online]. Available at: https://www.splcenter.org/20171004/frequently-asked-questions-abouthate-groups\#hate $\% 20$ group 